\title{
Science journalism: the standardisation of information from the press to the internet
}

\section{María Dolores Olvera-Lobo and Lourdes López-Pérez}

\begin{abstract}
The standardisation and selectivity of information were characteristics of science journalism in the printed medium that the digital editions of journals have inherited. This essay explores this fact from the international perspective, with a special focus on the Spanish case.
\end{abstract}

Keywords

Science and media; Science communication: theory and models; Science writing

Introduction

For more than a century science journalists have acted as mediators between science and the general public, thus taking on the task of conveying the progress of research and contributing, with their educational role, to shaping the critical opinion on scientific and technological development [Treise and Weigold, 2002]. Hence, it is possible to say that they have been the main creators of the social image of scientific research that has been projected.

Scientists have often made reference to the journalism specialising in their field. The "misty mirror" of science [Bucchi and Mazzolini, 2003], a reductive simplification of the scientific method [Weilgod, 2001], or the promotion of sensationalist pseudoscience [Gorney, 1992] are a few instances of the criticism addressed to scientific journalism. Such criticism is in contrast with the acknowledgement of the relationship of mutual dependence science and journalism have [Hartz and Chappell, 1997], and the role of the media as the main source of scientific information for citizens [Lieverouw, 1990; Nelkin, 1996; Treise and Weigold, 2002; Burns, O'Connor and Stocklmayer, 2003; Shäfer, 2010].

The importance of the role the media play in science dissemination - a field that has been extensively studied — justifies the interest of scholars [Grunig, 1974; Jerome, 1986; Lewestein, Allaman and Parthasarathy, 1998].

The works that have been published mainly focus on three areas, namely the coverage of science in the media in quantitative and qualitative terms [Fishman, 1980; Hansen, 1994; Pellechia, 1997; Metcalfe and Gascoigne, 1995; Weilgod, 2001; Dimopoulos and Koulaidis, 2002; Bucchi and Mazzolini, 2003; Peters et al., 2008; Dunwoody, 2009; Suleski and Ibaraki, 2010], precision and rigour in the media representation of science [Ryan and Owen, 1977; Ryan, 1979; Trumbo, Dunwoody and Griffin, 1998; Nisbet et al., 2002; Singer, Rogers and Glassman, 1991], and the 
relationship between journalists and scientists [Tankard and Ryan, 1974; Pulford, 1976; Durant, Evans and Thomas, 1992; Hansen, 1994; Hartz and Chappell, 1997; Gibbons, 1999; Weilgod, 2001; Nisbet et al., 2002; Suleski and Ibaraki, 2010].

The emergence of the Internet and its impact on science journalism is a new subject of study for scholars who focus on issues such as the standardisation of information [Granado, 2011], the difficulty to study the impact of science coverage onto the general public through a medium which carries content that is easily modifiable [Riesch, 2011], or the interaction with the audiences and its role in the overall representation of science [Brossard and Schefeule, 2013].

This paper analyses a number of aspects that are essential to understand the current state of science journalism, as well as the needs for future research. We also present a brief bibliographic review of the Spanish studies that have been conducted about science journalism and the very rare ones - as is the case at the international level - that address how scientific information is handled on the Internet.

Coverage: the supremacy of high-impact journals and the "medicalisation of information"
As concerns the study on the coverage of scientific information in the media, the two subjects with greater prominence in the literature are: the sources of information that are cited and the scientific areas dealt with. Before delving deeper into the aspects that have been analysed in these two areas, it should be emphasised that most of the research on science journalism has focused on printed journals, which have been considered as the main medium to learn about the progress of science [Weilgod, 2001].

The coverage of science in the media has been defined as one of the most standardised and selective across all the specialised areas of journalistic information [Hansen, 1994].

\subsection{Standardised coverage}

Science journals and the press releases from organisations are threatening the neutrality and objectivity of science journalism professionals who are restrained by the same embargoes and cite the same sources regardless of the country in which they work. A study by Granado [2011] — which collects the responses of 208 science journalists from 102 printed journals and agencies in 14 countries of the European Union - concludes that the majority of professionals in this area confess they are "slaves" to high-impact journals.

While acknowledging that they somehow feel manipulated by them, science journalists also admit their reliance on science journals to generate news [Nelkin, 1995]. Still on this point, in a study based on interviews with science journalists, Williams and Clifford [2009] point out that journalists working in this field confess they do not have time to do original reporting. They have to deal with a day-to-day schedule that includes the convocation of events such as congresses, press conferences, press releases, political summits, as well as with the announcement of scientific results published by some of the major scientific journals such as Nature, Science, and the British Medical Journal. 
This is the same point made by Veneu, Amorim and Massarani [2008], who note that the pieces of news are generated on the basis of the information produced by the scientific community such as the press releases issued by the institutions, or the very articles published in high-impact journals. However, other studies - like Weitkamp [2003] - mention the press releases from the government and the industry as an information source for the majority of the pieces of news, limiting high-impact journals to a source for only $15 \%$ of the pieces of news analysed.

Very frequently in the newsrooms around the world, the scientific news that is being published is nothing else than an edited version of the press releases forwarded by the press offices of specialised journals [Bartlett, Sterne and Egger, 2002; De Semir, Ribas and Revuelta, 1998; Stryker, 2002]. This is why the majority of the media reports converge on the subjects deal with, but also on the sources and the approach. It is what has been called spoon-fed scientific journalism [Russell, 2008], i.e. one that feeds almost exclusively on two sources of information, namely research centres and scientific journals.

The difficulties that journalists have in judging the validity, impact and implications of much of the science that they cover [Hansen, 1994] also have an influence on this fact. Validation routines are limited to the consultation of high-impact journals, uncritically accepting that the most important thing is what is reported by the scientific journal [Fishman, 1980; Hansen, 1994].

In addition, the critical aspects involved in the peer review process are not taken into account. In that respect, Goirena and Garea [2002] listed some of them such as: the number of articles published without review by independent experts is unknown; detecting fraud can hardly happen as the raw data are not questioned; or the fact that certain articles are prioritised over others because of their media appeal.

This dependence also promotes the internationalisation of the subjects dealt with in the media, since high-impact journals are in English, and most of the authors of the published articles are English or American. This is an aspect also pointed out by Bucchi and Mazzolini [2003] who conducted a survey of science coverage in the Italian newspaper Corriere della Sera from 1946 to 1997, and determined that the source of the majority of the items was international, as opposed to a lower presence of research projects by Italian scientists and institutions which corresponded to the number of North American sources. This is a trend that occurs in other countries such as Canada [Einsiedel, 1992] but that is reversed in territories such as the U.K., where national science plays a greater role. This conclusion is supported by works such as the research by Bauer [1995], which found out that $68 \%$ of science-oriented articles published in British newspapers between 1946 and 1990 have as a reference source British scientists or research centres.

\subsection{Selective coverage}

Aside from standardised, the coverage of science information is selective, up to the point that many authors have spoken of a "medicalisation of science news" [Einsiedel, 1992; Jerome, 1986; Pellechia, 1997; Bauer, 1998; Bucchi and Mazzolini, 2003; Weitkamp, 2003]. 
In a study conducted by Suleski and Ibaraki [2010] to evaluate science coverage in Times and NBC News, this prioritarisation was clearly highlighted by pointing out that $92.4 \%$ of the science-related reports that appeared in such media were in connection with medicine and healthcare.

Dennis and McCartney [1979] reached the same conclusion in a study of American metropolitan newspapers which appeared to favour the information on health or the environment versus other scientific areas such as physics or basic science.

The same trend appears in the research by Pellechia [1997], who discovered that biology and medicine are present in more than half of the science-related articles published by the Italian newspaper Corriere della Sera. However, in the latter case it should also be noted that, although medicine is featured more frequently than any other area, physics and astronomy are the disciplines that appear more in the headlines on the covers.

Social sciences represent the subject that is most distorted in the journalistic reconstruction of science [Fernández de Lis, 2013].

The impact of the Internet on Science Journalism
The coverage of science on the digital editions of the media has not been extensively studied by the scholars of public communication of science. The lack of works on the subject has been brought to the attention of the academic world by eminent authors such as Brossard and Schefeule [2013], who affirmed that it was urgent to analyse the way traditional media treat science in their digital versions.

The changes brought about by this new channel in journalistic routines and the little relevance that science has had on the printed editions of newspapers and other media since the 1990s demand that research be focused on this area from different perspectives, which should discover whether the standardisation and selectivity trend observed in the printed media has been maintained in the press or conversely the advent of the Internet has made it possible to overcome this issue. However, this type of analysis is interesting to establish whether the new Web 2.0 instruments will facilitate the production of 'original reportages' that we mentioned in the previous paragraphs. The published scientific literature has not reviewed these issues, which should be subjected to future research, although some studies mainly focused on the change in the access to sources [Curtin and Rhodenbaugh, 2001; Gans, 2010; Hu and Sundar, 2010; Granado, 2011] have given a clue about the future of science journalism in these new media.

The Internet has changed science journalism in three key areas, namely the production of news, the participation of the public with regard to the verification of the information, and the re-mediation of all the media through a single channel [Bolter and Grusin, 1999].

Other authors such as Williams and Clifford [2009] and Amend and Secko [2011] and Bauer et al. [2013], have been more critical and have pointed out the loss of information quality due to immediacy and superficiality as one of the aspects that currently mark this channel.

The access to sources is one of the steps of the news production process that has been most affected. Journalists look for news without leaving the editorial office 
[Granado, 2011]. In fact, according to a study by this author and based on interviews with science journalists, professionals specialising in this area spend an average of 2 to 3 hours daily browsing the Internet, and they emphasise that this channel has facilitated direct contact with scientists, the expansion of information and the access to documents that were previously unavailable. On the other hand, these advantages seem to go against the preservation of one of the fundamental principles in journalism, namely plurality.

The neutrality and objectivity of journalists has been threatened in that the information accessed by journalists has become standardised, and the routine of going around to look for news has turned into a few mouse clicks in front of a computer with no need of leaving the newsroom [Granado, 2011; Tanner, 2004]. The Internet has even increased journalists' dependence on high-impact journals [Granado, 2011]. Scientific information is now less diverse and more standardised than before owing to the concentration of science journalists in a few sources. The media follow the same sources regardless of the country in which they perform their activity. The report The State of News Media 2006 [Project for Excellence in Journalism, 2006] reinforces this idea by pointing out that the new paradox of journalism is a coverage limited to only a few stories, which — far from contrasting the standardisation of information that characterised the coverage of science in the papers - has only made it worse in the digital media. However, this is more of a perception, as we have not found any studies analysing the sources of science-related pieces of news published in the digital media and thus supporting this hypothesis.

According to Kiernan [1998] high-impact journals have gained prominence in the digital editions. The lack of human resources and the crisis that has invested journalism (scientific journalism in particular) do not seem to have stopped with the emergence of the Internet, but rather the loss of information control that has hit the printed media seems to have become more noticeable [Kiernan, 1998]. The larger role played by high-impact journals and reports also seems to be affecting other aspects in that certain territories are gaining prominence over others, based on the nationality of the journals. The European Commission has addressed this issue in the White Paper on a European Communication Policy [2006], stating that the coverage of European science is very limited. The vast majority of the news items published by high-impact journals come from North-American centres and institutions. In turn, such news items represent one of the main resources of the media, which creates a loop implying that the science produced outside the circle of high-impact journals has no place on the information agenda.

An approach to research on science journalism in Spain
The sources of information and the formal analysis of journalistic discourse are the two most discussed aspects in scientific journalism studies by Spanish authors.

As it happens at the international level, the constant reference to high-impact journals as sources of primary information has been the focus of the main empirical studies published in Spain [De Semir, 2000; Elías, 2002; Elías, 2002b; Goirena and Garea, 2002; Fernández-Muerza, 2005; Pont-Sorribes, Rovira and Di Bonito, 2013].

Most authors agree on the general tendency that can be found in the Spanish media to the standardisation of scientific information. They also speak of mimicry 
[De Semir, 2000] or 'circular circulation' of information [Bourdieu, 2003], in the sense that a number of media cover the same news as their competitors, and in turn they all pay attention to the international reference papers such as The New York Times, The Times or Le Monde, among others.

The carbon-copy selection of the subjects to be covered is primarily the result of the current heavy dependence of the Spanish science journalism on specialised journals. Specifically, a reliance on a limited number of journals, which are not always the ones with the greatest impact. On the contrary, it has to do rather with a prominence coming from the communication strategies developed by the same journals [González-Alcaide, Valderrama-Zurián and Aleixandre-Benavent, 2009].

Nature and Science are the most frequent sources for Spanish media [Ribas, 1998; De Semir, 2000; Goirena and Garea, 2002; Elías, 2002; Elías, 2002b;

Fernández-Muerza, 2005; González-Alcaide, Valderrama-Zurián and Aleixandre-Benavent, 2009; Pérez-Bahón, 2010]. This propensity to 'lazy' journalism [De Semir, 2013] leaves to two or three science journals the selection of the items of science information that deserve to make the headlines. They are the main players in the so-called media 'agenda setting' phenomenon, whereby they impose on the citizens the events that they deem newsworthy [Elías, 2002].

Their value as sources of reliable information translates into a tendency to consider as the correct science journalism one that is based on reference journals as sources of information. This tendency is even more marked in the case of medicine-specialised journals [De Semir, 1996]. A study by this author on the pieces of news published in El País, La Vanguardia and $A B C$ has confirmed the prominence of The Lancet and Nature as sources of information for journalists in Spain.

Thus, in the case of science journalism, the information is subjected to a double assessment of newsworthiness. First, high-impact journals decide whether a piece of information is newsworthy and thereafter follows a thematisation by journalists and editors. This causes a monopolisation of science journalism [Ribas, 1998; González-Alcaide, Valderrama-Zurián and Aleixandre-Benavent, 2009] and foments a few well-defined information circuits, both geographic and scientific [Fernández-Muerza, 2005]. In the former case, this is due to the predominance of the English-speaking world, especially the US, and in the latter case, this is due to the importance given to researchers based on the country they work in - and, once again, the centres from the English-speaking world play a greater role than the national ones.

Moreover, within national borders, some geographic areas prevail over others. This produces what Elías [2002a] has defined as 'centralised' journalism, meaning that the only opinion that matters is the one of the researchers from the capital city.

While high-impact journals certainly play an important role, that is also true for government sources, especially in more specialised fields, such as healthcare. In this regard, a study on the coverage of medical information in El País, El Mundo, La Vanguardia, El Periódico de Cataluña and ABC between 1997 and 2004 [Revuelta, 2006] highlighted the importance of government sources, on which as much as $49 \%$ of the published pieces of news were based. 
This reliance on official sources is shared by all the media, which is another reason for the standardisation of the published news and generates a biased and focused view on a few topics. The prioritisation of a few scientific facts influences the importance that society gives to some subjects over others [Revuelta, 2006].

The emergence of the Internet in science journalism does not seem to have changed this dependence on science journals, but quite the opposite, the situation has even worsened [Pérez-Bahón, 2010]. The use of the Internet has made it possible for specialised journalists to save time as they do not have to leave their office in search of news sources.

The Internet has turned into a reactivation factor that allows certain producers of information with an interest to strengthen its penetration into the newsrooms. This standardisation appears not only as concerns the sources of information, but also in relation to the subjects dealt with. Medicine [Elías, 2002a; Goirena and Garea, 2002; González-Alcaide, Valderrama-Zurián and Aleixandre-Benavent, 2009; Pérez-Bahón, 2010], environment [Goirena and Garea, 2002; González-Alcaide, Valderrama-Zurián and Aleixandre-Benavent, 2009], and archaeology [González-Alcaide, Valderrama-Zurián and Aleixandre-Benavent, 2009] are the most recurrent themes in the science news published by the Spanish media.

As we mentioned above, within the public communication of science, scientific journalism certainly is the field scholars have paid more attention to. However, there are very few studies that evaluate the impact of the Internet on the treatment of scientific information in the media.

This is something vital to learn about the present and the future of the specialisation in this area. This is why the empirical evaluation of science-related pieces of news published in digital editions is extremely interesting.

\section{Translated by Massimo Caregnato}

\section{References}

Amend, E. and Secko, D. (2011). 'In the Face of Critique: A Metasynthesis of the Experiences of Journalists Covering Health and Science'. Science Communication 34 (2), pp. 241-282. DOI: 10.1177/1075547011409952.

Anderson, A. A., Brossard, D., Scheufele, D. A., Xenos, M. A. and Ladwig, P. (2014). "The "Nasty Effect:" Online Incivility and Risk Perceptions of Emerging Technologies'. Journal of Computer-Mediated Communication 19 (3), pp. 373-387. DOI: $10.1111 /$ jcc4.12009.

Bartlett, C., Sterne, J. and Egger, M. (2002). 'What is newsworthy? Longitudinal study of the reporting of medical research in two British newspapers'. British Medical Journal 325 (7355), pp. 81-84. DOI: 10.1136/bmj .325.7355.81.

Bauer, M. (1995). Science and Technology in the British Press, Research report, 1946-1990. London, U.K.: Science Museum.

- (1998). 'The medicalization of science news from the 'rocket-scalpel' to the 'genemeteorite' complex'. Social Science Information 37, pp. 731-751. DOI: 10.1177/053901898037004009. 
Bauer, M. W., Howard, S., Ramos, Y. J. R., Massarani, L. and Amorim, L. (2013). Global Science Journalism Report. Working conditions \& Practices, Professional Ethos and Future Expectations. London, U.K.: Science and Development Network. URL: http:

//eprints.1se.ac.uk/48051/1/Bauer_Global_science_journalism_2013.pdf (visited on 16th December 2014).

Bolter, J. and Grusin, R. (1999). Remediation. Understanding New Media. Cambridge, U.S.A.: MIT Press.

Bourdieu, P. (2003). El oficio de científico. Ciencia de la ciencia y reflexividad. Barcelona, Spain: Anagrama.

Brossard, D. and Schefeule, D. (2013). 'Science, New Media and The Public'. Science 339 (6115), pp. 40-41. DOI: 10.1126/science.1232329.

Bucchi, M. and Mazzolini, R. (2003). 'Big Science, little news: science coverage in the Italian daily press, 1946-1997'. Public Understanding Science 12, pp. 7-23. DOI: 10.1177/0963662503012001413.

Burns, T., O'Connor, D. and Stocklmayer, S. (2003). 'Science Communication: A Contemporary Definition'. Public Understanding of Science 12, pp. 183-202. DOI: 10.1177/09636625030122004.

Commission of the European Communities (2006). White Paper on a European Communication Policy. Brussels, Belgium: Commission of the European Communities.

Curtin, P. and Rhodenbaugh, E. (2001). 'Building the news media agenda on the environment: A comparison of public relations and journalistic sources'. Public Relations Review 27 (2), pp. 179-195.

De Semir, V. (1996). '¿Qué hechos merecen ser noticia?' The Lancet [ed. esp.] 29, pp. 185-189. URL: http://www . unirioja.es/comunicaciencia/contenido/ uploads/archivos/merecensernoticia.pdf.

Original: De Semir, V. (1996), 'What is newsworthy?' The Lancet 347, pp. 1163-1166.

- (2000). ‘Periodismo científico, un discurso a la deriva'. Discurso y sociedad 2 (2), pp. 9-37.

- (2013). ‘Protagonistas y públicos de la comunicación científica'. In: El científico ante los medios de comunicación. Retos y herramientas para una cooperación fructífera. Madrid, Spain: Cuadernos de la Fundación Dr. Antonio Esteve, pp. 1-8.

De Semir, V., Ribas, C. and Revuelta, G. (1998). 'Press releases of science journal articles and subsequent newspaper stories on the same topic'. JAMA: Journal of the American Medical Association 280 (3), pp. 294-295. DOI: 10.1001/jama.280.3.294.

Dennis, E. and McCartney, J. (1979). 'Science journalists on metropolitan dailies'. Journal of Environmental Education 10, pp. 10-11. DOI: 10.1080/00958964.1979.9942627.

Dimopoulos, K. and Koulaidis, V. (2002). 'The socio-epistemic constitution of science and technology in the Greek press: an analysis of its presentation'. Public Understanding of Science 11, pp. 225-241. DOI: 10.1088/0963-6625/11/3/302.

Dunwoody, S. (2009). 'Science Journalism'. In: Handbook of Public Communication of Science and Technology. Ed. by M. Bucci and B. Trench. New York, U.S.A.: Routledge.

Durant, J., Evans, G. and Thomas, G. (1992). 'Public Understanding of Science in Britain: The role of medicine in the popular representation of science'. Public Understanding of Science 1, pp. 161-182. DOI: 10.1088/0963-6625/1/2/002. 
Einsiedel, E. (1992). 'Framing science and technology in the Canadian press'. Public Understanding of Science 1, pp. 89-101. DOI: 10.1088/0963-6625/1/1/011.

Elías, C. (2002). 'Influencia de la revistas de impacto en el periodismo científico y en la ciencia actual'. Revista Española de Investigaciones Sociológicas 98, pp. 123-137.

Elías, C. (2002a). 'La revista Nature en las noticias de prensa'. Comunicar 19, pp. 37-41.

- (2002b). 'Periodistas especializados en ciencia: formación, reconocimiento e influencia'. Mediatika 8, pp. 389-403.

Entwistle, V. (1995). 'Reporting research in medical journals and newspapers'. British Medical Journal 310 (6984), pp. 920-923.

Fernández de Lis, P. (2013). Ciencia y periodismo en la Red. Vol. 28. Madrid, Spain: Cuadernos de la Fundación Antonio Esteve.

Fernández-Muerza, A. (2005). 'La información científica en la prensa de referencia: el caso espanñol a partir de un anailisis comparativo'. Zer 19, pp. 205-232.

Fishman, M. (1980). Manuctaring the News. Austin, U.S.A.: University of Texas Press.

Gans, H. (2010). 'News and the news media in the digital age: Implications for democracy'. Daedalus 139 (2), pp. 8-17. DOI: 10.1162/daed.2010.139.2.8.

Gibbons, M. (1999). 'Science's New Social Contract with Society'. Nature 402, pp. C81-C84.

Goirena, J. and Garea, M. (2002). 'La salud de la información científica'. Mediatika 8, pp. 523-558.

González-Alcaide, G., Valderrama-Zurián, J. C. and Aleixandre-Benavent, R. (2009). 'La investigación sobre la divulgación de la ciencia en España: situación actual y retos para el futuro'. Arbor Ciencia, Pensamiento y Cultura 185 (738), pp. 861-869. DOI: 10.3989 /arbor. $2009.738 \mathrm{n} 1058$.

Gorney, C. (1992). ‘Numbers versus pictures: Did network television sensationalize Chernobyl coverage?' Journalism Quarterly 69, pp. 455-465. DOI: 10.1177/107769909206900219.

Granado, A. (2011). 'Slaves to journals, serfs to the web: The use of the Internet in newsgathering among European science journalists'. Journalism 12 (7), pp. 794-813. DOI: $10.1177 / 1464884911412702$.

Grunig, J. (1974). 'Three stopping experiments on the communication of science'. Journalism Quarterly 51, pp. 387-399.

Hansen, A. (1994). 'Journalistic practices and science reporting in the British press'. Public Understanding Science 3 (2), pp. 111-134. DOI: 10.1088/0963--6625/3/2/001.

Hartz, J. and Chappell, R. (1997). Worlds Apart: How the Distance between Science and Journalism Threatens America's Future. Nashville, TN, U.S.A.: First Amendment Center.

$\mathrm{Hu}$, Y. and Sundar, S. (2010). 'Effects of online health sources on credibility and behavioral intentions'. Communication Research 37 (1), pp. 105-132.

Jerome, F. (1986). 'Prospect for science journalism'. In: Reporting science: The case of aggression. Ed. by H. Goldstein, pp. 147-154.

Kiernan, V. (1998). 'Mars meteorite: A case study in controls of dissemination of science news'. In: Annual meeting of the Association for Education in Journalism and Mass Communication. Conference Proceedings. (Baltimore, U.S.A. 5th-8th August 1998). 
Lewestein, B., Allaman, T. and Parthasarathy (1998). 'Historical survey of media coverage of biotechnology in the United States 1970-1996'. In: Annual meeting of the Association for Education in Journalism and Mass Communication. Conference Proceedings. (Baltimore, U.S.A. 5th-8th August 1998).

Lieverouw, L. (1990). 'Communication and the Social Representation of Scientific Knowledge'. Critical Studies in Mass Communication 7, pp. 1-10. DOI: 10.1080/15295039009360159.

Metcalfe, J. and Gascoigne, T. (1995). 'Science journalism in Australia'. Public Understanding of Science 4, pp. 411-428. DOI: 10.1088/0963-6625/4/4/005.

Nelkin, D. (1995). Selling Science: How the press cover science and technology. New York, U.S.A.: Freeman.

- (1996). 'An Uneasy Relationship: The Tensions between Medicine and the Media'. The Lancet 347, pp. 1600-1603.

Nisbet, M. C., Scheufele, D. A., Shanahan, J., Moy, P., Brossard, D. and Lewenstein, B. V. (2002). 'Knowledge, Reservations, or Promise? A Media Effect Model for Public Perceptions of Science and Technology'. Communication Research 29, pp. 584-608. DOI: 10.1177/009365002236196.

Pellechia, M. (1997). 'Trends in Science Coverage: A Content Analysis of Three US Newspapers'. Public Understanding of Science 6, pp. 49-68. DOI: 10.1088/0963-6625/6/1/004.

Pérez-Bahón, F. (2010). 'Reflejo del uso de internet como fuente en la información de salud. Anailisis de los principales diarios generalistas espanñoles'. Textual $\mathcal{E}$ Visual Media 3, pp. 167-198.

Peters, H. P., Brossard, D., Cheveigné, S. de, Dunwoody, S., Kallfass, M., Miller, S. and Tsuchida, S. (2008). 'Science-Media Interface: It's time to Reconsider'. Science Communication 30 (2), pp. 266-276. DOI: 10.1177/1075547008324809.

Pont-Sorribes, C., Rovira, S. Cortinñas and Di Bonito, I. (2013). 'Retos y oportunidades para los periodistas científicos en la adopción de las nuevas tecnologías: el caso de Espanña'. JCOM 12 (3), A05. URL: http://jcom.sissa.it/archive/12/3-4/JC0M1203\%282013\%29A05.

Project for Excellence in Journalism (2006). The State of News Media 2006. URL: http://www . journalism.org.

Pulford, D. (1976). 'A follow-up study of science news accuracy'. Journalism Quarterly 53, pp. 119-121.

Revuelta, G. (2006). 'Salud y medios de comunicación en España'. Gaceta Sanitaria 20 (1), pp. 203-208.

Ribas, C. (1998). 'La influencia de los press release, según con el cristal con el que se mire'. Quark 10, pp. 32-37. ISSN: 1135-8521. URL: http://dialnet.unirioja.es/servlet/articulo?codigo=230273.

Riesch, H. (2011). 'Changing new: re-adjusting science studies to online newspapers'. Public Understanding Science 20 (6), pp. 771-777. DOI: $10.1177 / 0963662510376342$.

Russell, C. (2008). Science reporting by press release. An old problem grows worse in the digital age. URL: http://www.cjr.org/the_observatory/science_reporting_ by_press_rel.php?page=all (visited on 1st January 2015).

Ryan, M. (1979). 'Attitudes of scientists and journalists towards media coverage of science news'. Journalism Quarterly 56, pp. 18-26.

Ryan, M. and Owen, D. (1977). 'An accuracy survey of metropolitan newspaper coverage of social issues'. Journalism Quarterly 54, pp. 27-32. 
Shäfer, M. (2010). 'Taking stock: A meta-analysis of studies on the media's coverage of science'. Public Understanding Science 21 (6), pp. 650-663. DOI: 10.1177/0963662510387559.

Singer, E., Rogers, T. and Glassman, M. (1991). 'Public opinion about AIDS before and after the 1988 U.S. government public information campaign'. Public Opinion Quarterly 68, pp. 48-58.

Stryker, J. (2002). 'Reporting medical information: Effects of press releases and newsworthiness on medical journal articles' visibility in the news media'. Preventive Medicine 35 (5), pp. 519-530. DOI: 10.1006/pmed.2002.1102.

Suleski, J. and Ibaraki, M. (2010). 'Scientists are talking, but mostly to each other: a quantitative analysis of research represented in mass media'. Public Understanding Science 19 (1), pp. 115-205. DOI: 10.1177/0963662508096776.

Tankard, J. W. and Ryan, M. (1974). 'News Source Perceptions of Accuracy of Science Coverage'. Journalism Quarterly 51, pp. 219-225.

Tanner, A. (2004). 'Agenda building, source selection, and health news at local television stations'. Science Communication 24 (4), pp. 350-363. DOI: 10.1177/1075547004265127.

Treise, D. and Weigold, M. (2002). 'Advancing Science Communication: A Survey of Science Communication'. Science Communication 23, pp. 310-322. DOI: 10.1177/107554700202300306.

Trumbo, C., Dunwoody, S. and Griffin, R. (1998). 'Journalists, cognition, and the presentation of an epidemiologic study'. Science Communication 19, pp. 238-265. DOI: $10.1177 / 1075547098019003005$.

Veneu, F., Amorim, L. and Massarani, L. (2008). 'Science journalism in Latin America: How the scientific information from a scientific source is accommodated into a journalistic story'. Journal of Science Communication 7 (1), pp. 1-9.

Weilgod, M. (2001). 'Communicating Science. A review of the Literature'. Science Communication 3 (2), pp. 164-193. DOI: 10.1177/1075547001023002005.

Weitkamp, E. (2003). 'British Newspapers Privilege Health and Medicine Topics over other Science News'. Public Relations Review 29, pp. 321-333. DOI: 10.1016/S0363-8111(03.

Williams, A. and Clifford, S. (2009). Mapping the Field: A Political Economic Account of Specialist Science News Journalism in the UK National Media. London. U.K.: Department for Business, Innovation et al.

\section{Authors}

María Dolores Olvera-Lobo has graduated in Documentation Studies and is currently Professor of Information and Communication at the University of Granada, Spain. She is a member of the Scimago Group of the Spanish National Research Council (CSIC, Madrid). Both as an author and co-author, she has published books, essays and tens of articles in national and international journals with a certified quality index (JCR, SJR, RESH). Ph.: (+34) 627250367.

E-mail: molvera@ugr.es.

Lourdes López has graduated in Communication Science and has obtained a Master degree in Science Information and Communication at the University of Granada, Spain and one in Marketing and Commercial Management at ESIC 
Business School. Her professional career has developed within the area of Science Communication, as a conference speaker, a teacher, and author of a number of articles and book chapters. Ph.: (+34) 652302109.

E-mail: lourdeslopez@correo.ugr.es.

How to cite

Olvera-Lobo, M. D. and López-Pérez, L. (2015). 'Science journalism: the standardisation of information from the press to the internet'.

JCOM 14(03), Y01_en.

This article is licensed under the terms of the Creative Commons Attribution - NonCommercial NoDerivativeWorks 4.0 License.

ISSN 1824 - 2049. Published by SISSA Medialab. http:/ /jcom.sissa.it/. 